\title{
KAJIAN EKSPERIMENTAL POLA RETAK PADA PORTAL BETON BERTULANG AKIBAT BEBAN QUASI CYCLIC
}

\author{
Oscar Fithrah Nur ${ }^{1}$
}

\begin{abstract}
ABSTRAK
Kajian eksperimental ini dilakukan untuk mendapatkan kurva histeresis (beban - perpindahan) dan mempelajari pola retak dari model struktur portal beton bertulang akibat beban quasi cyclic. Penelitian ini dilakukan pada dua tipe model portal beton bertulang, yaitu portal kolom kuat balok lemah dan portal kolom - balok sama kuat. Pemberian beban quasi cyclic dilakukan dengan displacement control berdasaran siklus pembebanan yang telah ditetapkan sebelumnya, sampai portal mengalami keruntuhan atau mencapai perpindahan ultimit. Dari hasil eksperimental yang dilakukan, retak pertama sekali terjadi pada daerah tumpuan balok. Pada saat runtuh, retak pada umumnya terjadi pada daerah tumpuan balok dan daerah pertemuan antara balok dan kolom. Berarti, sendi plastis terjadi pada balok dan bukan pada kolom, atau keruntuhan pertama kali terjadi pada balok dan bukan pada kolom. Dengan demikian, portal kolom kuat - balok lemah dan portal kolom - balok sama kuat dapat digunakan pada bangunan yang terletak di daerah rawan gempa.
\end{abstract}

Kata Kunci : portal beton bertulang, beban quasi cyclic, kurva histeresis, pola retak.

\section{PENDAHULUAN}

\subsection{Latar Belakang}

Indonesia merupakan negara yang berada di daerah pertemuan tiga pelat/lempeng tektonik bumi, yaitu lempeng Samudra Hindia (Indo Australia), Eurasia dan Pasifik. Oleh karena itu, daerahdaerah di Indonesia pada umumnya rawan terhadap gempa. Dalam beberapa kejadian gempa di Indonesia beberapa tahun belakangan ini, banyak bangunan yang terbuat dari struktur beton bertulang yang mengalami kerusakan dan bahkan mengalami keruntuhan. Hal ini pada umumnya disebabkan karena elemen kolom pada struktur portal beton bertulang tidak sanggup memikul beban siklik akibat goyangan gempa yang terjadi.

Kajian eksperimental untuk mempelajari perilaku dari portal beton bertulang sampai mengalami keruntuhan akibat beban siklik (beban tekan - tarik) perlu dilakukan untuk menguji kehandalan struktur, yaitu dengan mengetahui beban maksimum yang dapat dipikul struktur dan besarnya perpindahan struktur akibat goyangan gempa, serta pola retak yang terjadi pada struktur portal tersebut. Penelitian ini dilakukan untuk mendapatkan perilaku yang terbaik dari dua model portal beton bertulang dalam menahan beban siklik akibat goyangan gempa, yaitu portal kolom kuat balok lemah dan portal kolom - balok sama kuat.

\subsection{Tujuan dan Manfaat Penulisan}

Adapun tujuan dari penelitian yang dilakukan ini adalah :

- Untuk mendapatkan hysteresis loop (kurva hubungan beban - perpindahan) pada portal beton bertulang akibat beban siklik.

- Untuk mengetahui pola retak yang terjadi pada portal beton bertulang akibat beban siklik.

\footnotetext{
${ }^{1}$ Staf Pengajar Jurusan Teknik Sipil Fakultas Teknik Universitas Andalas, e-mail: oscar@ft.unand.ac.id
} 


\section{DASAR TEORI}

\subsection{Sistem Struktur}

Sebelum mengetahui berbagai macam sistem struktur, prinsip kinerja struktur terlebih dahulu harus diketahui untuk dapat menentukan macam struktur yang mungkin terjadi.

\section{Gambar 1. Kinerja Struktur terhadap Beban}

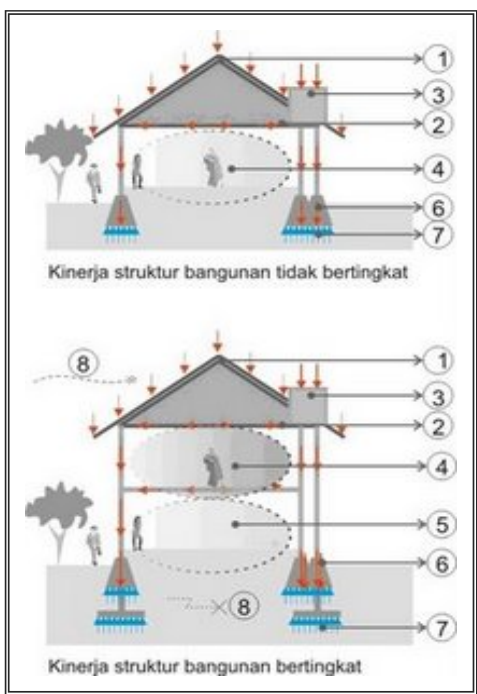

Sistem struktur bangunan gedung intinya bekerja menyalurkan beban bangunan sehingga menjaga bangunan tetap berdiri dan membentuk ruang fungsi. Beban-beban yang terjadi pada bangunan gedung berasal dari berat struktur (berat sendiri, beban mati ; (1), (2) dan (3)) dan berat fungsi (beban berguna, berat hidup ; (4) dan (5) didalamnya serta akibat pengaruh gaya luar seperti gempa dan badai (8). Berat struktur dihitung dari semua elemen struktur dari atap sampai pondasi. Berat fungsi tergantung jenis dan volume kegiatan yang diwadahi bangunan, sedangkan beban gaya luar dipengaruhi oleh bentuk, letak dan posisi bangunan. Beban-beban itu disalurkan dari atas ke bawah, mulai dari elemen rangka atap, rangka utama atap, pelat lantai, rangka utama kolom balok atau dinding pemikul, dan sampai pada pondasi (6) dan diteruskan ke dalam tanah (7). Kolom dan balok meneruskan gaya menurut arah garis dan dinding menurut arah bidangnya.

Pada sistem struktur portal beton bertulang, balok utama yang langsung ditumpu oleh kolom, dianggap menyatu secara kaku dengan kolom. Sistem kolom dan balok utama seperti ini dikatakan sebagai sistem portal. Sistem portal telah lama dipakai sebagai sistem bangunan yang menahan beban gravitasi dan lateral akibat gempa. Sistem ini memanfaatkan kekakuan balok-balok utama dan kekakuan kolom.

\subsection{Filosofi Bangunan Tahan Gempa}

Dua faktor utama yang menjadi penyebab mengapa bangunan yang dibuat manusia tidak ada yang $100 \%$ tahan gempa adalah :

- Gempa merupakan suatu hal yang tidak dapat dipastikan dan bersifat acak, baik dalam hal besar maupun frekuensi terjadinya gempa.

- Manusia mempunyai kecendrungan untuk mengoptimalkan upaya-upaya agar disain terhadap gempa yang dilakukan lebih efisien dan ekonomis, sehingga selalu ada resiko yang diambil. Resiko yang diambil berkaitan dengan kebijakan untuk "membatasi" beban gempa rencana yang dipakai. Jadi, secara teoritis selalu ada kemungkinan bahwa pada suatu saat beban gempa rencana terlampaui. 
Secara umum, filosofi dari bangunan tahan gempa adalah sebagai berikut :

- Bila terjadi Gempa Ringan, bangunan tidak boleh mengalami kerusakan, baik pada komponen non-struktural (dinding retak, genteng dan langit-langit jatuh, kaca pecah) maupun pada komponen strukturalnya (kolom dan balok retak, pondasi amblas).

- Bila terjadi Gempa Sedang, bangunan boleh mengalami kerusakan pada komponen nonstrukturalnya, akan tetapi komponen struktural tidak boleh rusak.

- Bila terjadi Gempa Besar, bangunan boleh mengalami kerusakan baik pada komponen nonstruktural maupun komponen strukturalnya, akan tetapi jiwa penghuni bangunan tetap selamat, artinya sebelum bangunan runtuh masih cukup waktu bagi penghuni bangunan untuk keluar atau mengungsi ketempat aman.

Perbedaan utama dari beban gempa terhadap beban-beban lainnya dapat dikelompokkan atas :

- Beban gempa merupakan suatu beban dinamis, dimana terjadi sejumlah perubahan beban yang bersifat siklik. Sehingga penguasaan atas perilaku bangunan akibat beban gempa memerlukan pengertian atas dasar-dasar dinamika struktur.

- Disain struktur pada umumnya berdasarkan atas suatu standar atau code bangunan, yang menyatakan bahwa bangunan boleh rusak berat (suffer mayor damage) tetapi tidak boleh runtuh (should not collapse) akibat beban gempa rencana maksimum. Sedangkan untuk jenis beban yang lainnya, bangunan didisain tidak boleh rusak sama sekali akibat beban kerja (beban angin dan beban gravitasi).

\subsection{Perilaku Keruntuhan Beton Bertulang}

Beton bertulang dengan material beton merupakan material heterogen dari semen, mortar dan agregat batuan, yang properti mekaniknya bervariasi dan tidak terdefinisi dengan pasti. Hanya untuk memudahkan dalam analisa saja maka umumnya dianggap sebagai material homogen dalam konteks makro.

Perilaku keruntuhan beton dapat dibagi dalam tiga tahapan, yaitu : elastis penuh (belum retak), tahapan mulai terjadi retak-retak dan tahapan plastis (leleh pada baja atau beton pecah). Respon non-linier disebabkan dua hal utama yaitu : keretakan beton didaerah tarik dan tulangan mengalami leleh atau beton pecah (crushing) pada daerah desak. Selain itu juga disebabkan perilaku lain yang terkait, misalnya bond-slip antara tulangan baja dan beton disekitarnya, aksi penguncian agregat pada daerah retak dan akhirnya aksi angkur (dowel action) dari tulangan yang melintas disekitar retak. Perilaku sebagai fungsi waktu, misalnya creep, shrinkage dan variasi temperatur juga menyumbang perilaku non-linier. Kecuali itu, hubungan tegangan regangan beton tidak hanya bersifat non-linier, tetapi juga berbeda antara beban tekan dan tarik, sifat mekaniknya tergantung dari umur waktu dibebani dan kondisi lingkungan (suhu sekeliling dan kelembaban). Perilaku keruntuhan struktur beton bertulang dapat digambarkan dalam bentuk kurva beban - lendutan, seperti yang dapat dilihat pada Gambar 2 berikut.

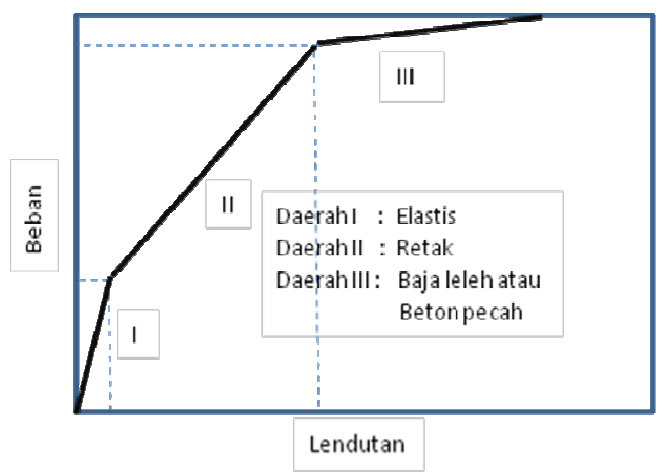

Gambar 2. Perilaku Beban - Lendutan Struktur Beton Bertulang 


\section{PENGUJIAN PORTAL BETON BERTULANG}

3.1 Benda uji portal

$60 \mathrm{~mm}$

$40 \mathrm{~mm}$

Penampang

$500 \mathrm{~mm}$

Balok

$60 \mathrm{~mm}$

$60 \mathrm{~mm}$

Penampang

Kolom

$630 \mathrm{~mm}$

Gambar 3. Dimensi Portal Kolom Kuat - Balok Lemah

$60 \mathrm{~mm}$

Penampang

$500 \mathrm{~mm}$

Balok

$60 \mathrm{~mm}$

$60 \mathrm{~mm}$

Penampang

Kolom

$630 \mathrm{~mm}$

Gambar 4. Dimensi Portal Kolom - Balok Sama Kuat

\subsection{Setup Pengujian}

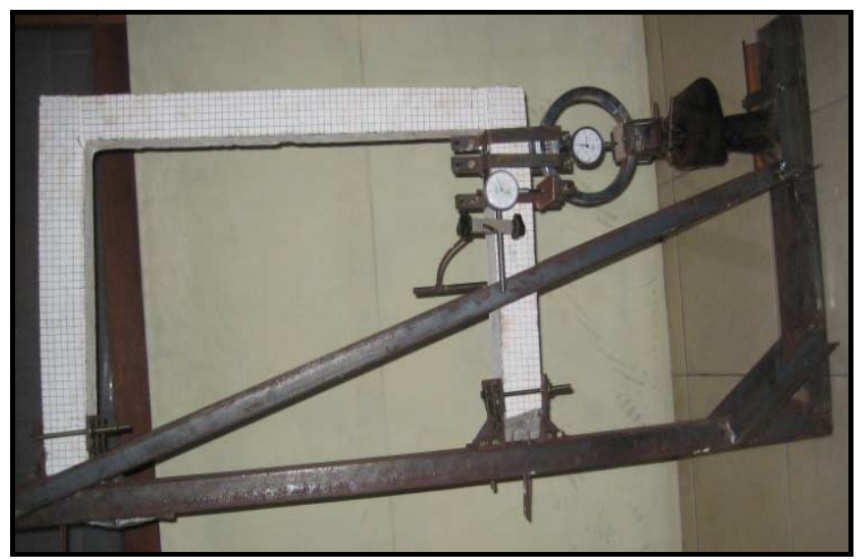

Gambar 5. Permodelan Pengujian di Laboratorium 


\section{ANALISIS DAN PEMBAHASAN}

\subsection{Benda Uji Kolom Kuat - Balok Lemah}

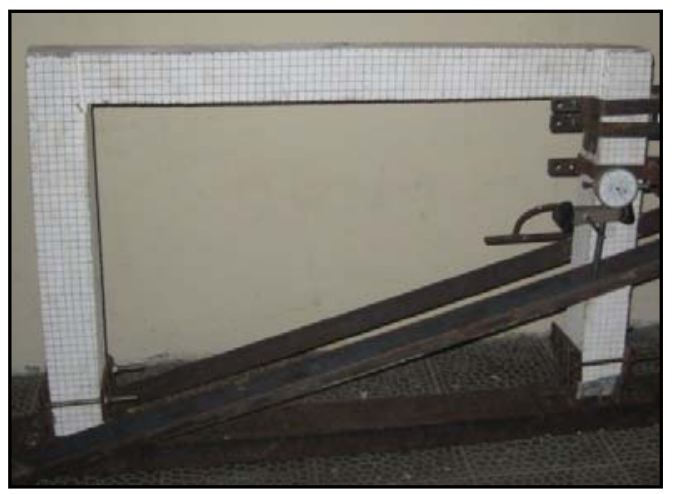

Gambar 6. Benda Uji Kolom Kuat - Balok Lemah

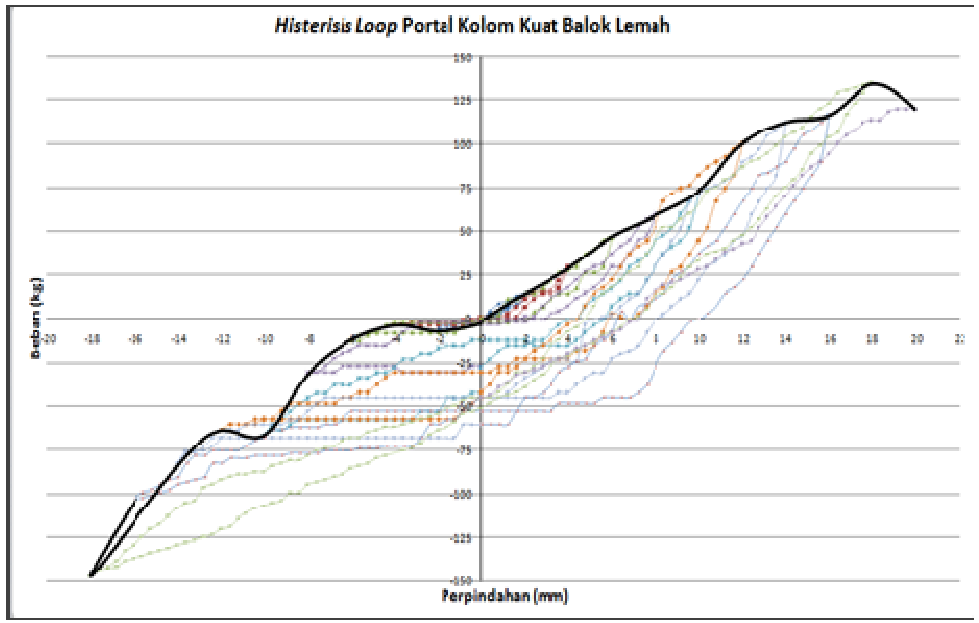

Gambar 7. Kurva Histeresis Kolom Kuat - Balok Lemah

\subsubsection{Kondisi Tekan}

1. Retak Pertama

Pada benda uji portal tipe 1, retak pertama berada pada sendi plastis yaitu pertemuan kolom dengan balok. Dari pengamatan pola retak yang terjadi pada benda uji, kolom yang pertama kali mengalami retak diikuti dengan retak pada balok. Retak pertama ditandai dengan tidak liniernya kurva beban dengan perpindahan akibat beban dorong (tekan) sebesar 46,5 kg. Perpindahan yang terjadi pada retak pertama sebesar $6 \mathrm{~mm}$.

2. Kondisi Leleh

Pada saat leleh diikuti dengan retak-retak baru pada bagian sendi plastis lainnya. sedangkan tumpuan (dasar kolom) tidak mengalami keretakan. Beban dorong (tekan) pada saat leleh adalah sebesar 100,5 kg dengan perpindahan sebesar $12 \mathrm{~mm}$.

3. Kondisi Ultimit

Ini tejadi ketika beban yang mampu dipikul oleh portal adalah beban maksimum. Beban dorong (tekan) maksimum adalah sebesar $135 \mathrm{~kg}$, dengan perpindahan pada saat beban maksimum adalah sebesar $18 \mathrm{~mm}$. 
4. Keruntuhan Portal

Ini tejadi ketika beban tidak lagi bertambah dan beton mulai hancur. Beban dorong (tekan) pada saat runtuh adalah sebesar $120 \mathrm{~kg}$ dengan perpindahan sebesar $20 \mathrm{~mm}$.

\subsubsection{Kondisi Tarik}

1. Retak Pertama

Pada benda uji portal tipe 1, retak pertama berada pada sendi plastis, yaitu pertemuan kolom dengan balok. Dari pengamatan pola retak yang terjadi pada benda uji, kolom yang pertama kali mengalami retak diikuti dengan retak pada balok. Beban tarik pada saat retak pertama sebesar $4,5 \mathrm{~kg}$ dengan perpindahan sebesar $2 \mathrm{~mm}$.

2. Kondisi Leleh

Pada saat leleh diikuti dengan retak-retak baru pada bagian sendi plastis lainnya, pada tumpuan (dasar kolom) tidak mengalami keretakan. Beban tarik pada saat leleh adalah sebesar $60 \mathrm{~kg}$ dengan perpindahan sebesar 9,6 $\mathrm{mm}$.

3. Kondisi Ultimit

Ini tejadi pada saat portal memikul beban maksimum tarik, yaitu sebesar $147 \mathrm{~kg}$ dengan perpindahan pada saat beban maksimum tarik adalah sebesar $18 \mathrm{~mm}$.

4. Keruntuhan Portal

Ini tejadi ketika beban tidak lagi bertambah dan beton mulai hancur. Beban tarik pada saat hancur adalh sebesar $102 \mathrm{~kg}$ dengan perpindahan adalah sebesar $16 \mathrm{~mm}$.

\subsubsection{Pola Retak}
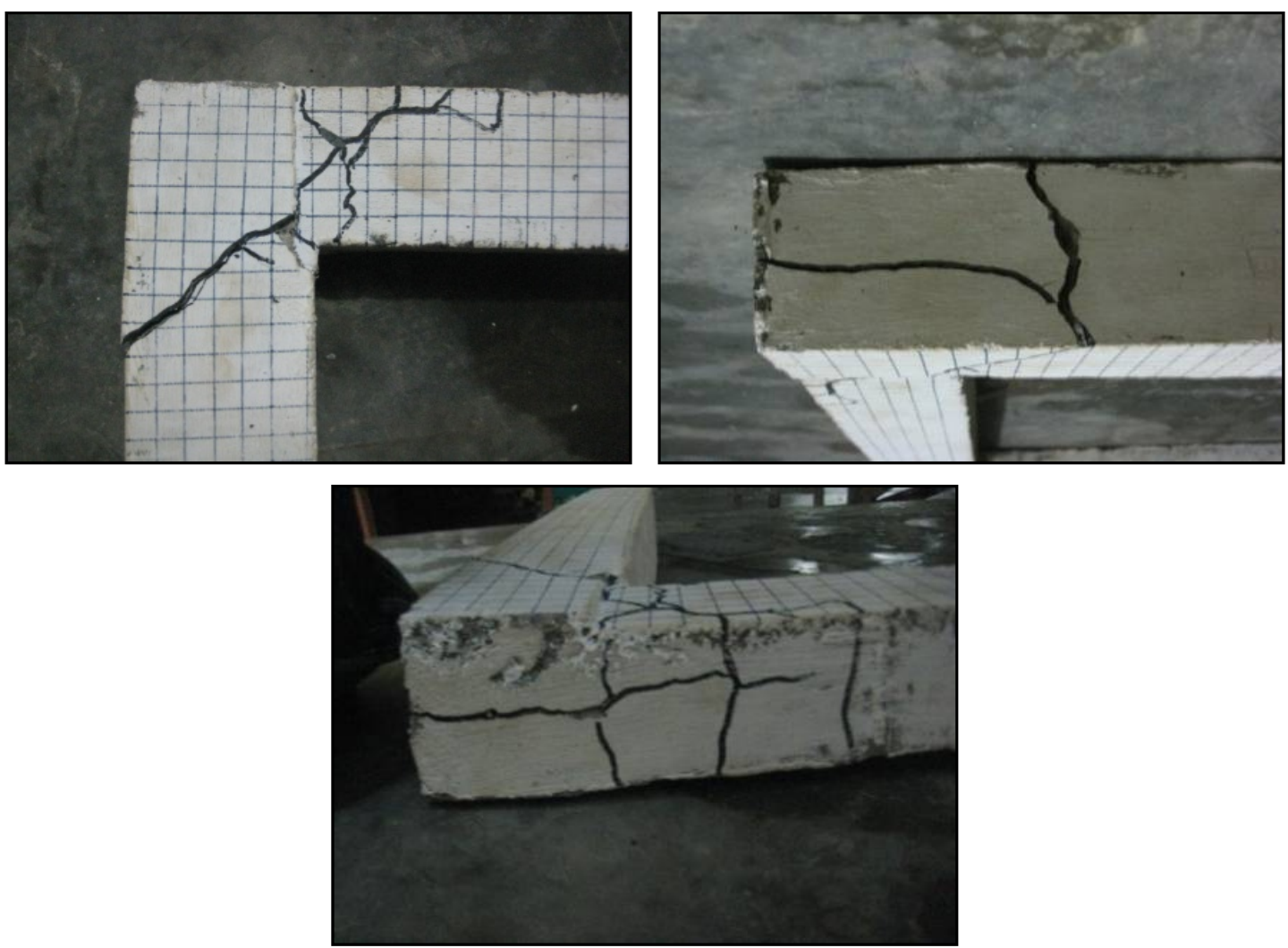

Gambar 8. Pola Retak pada Sisi Kiri Portal Kolom Kuat - Balok Lemah 

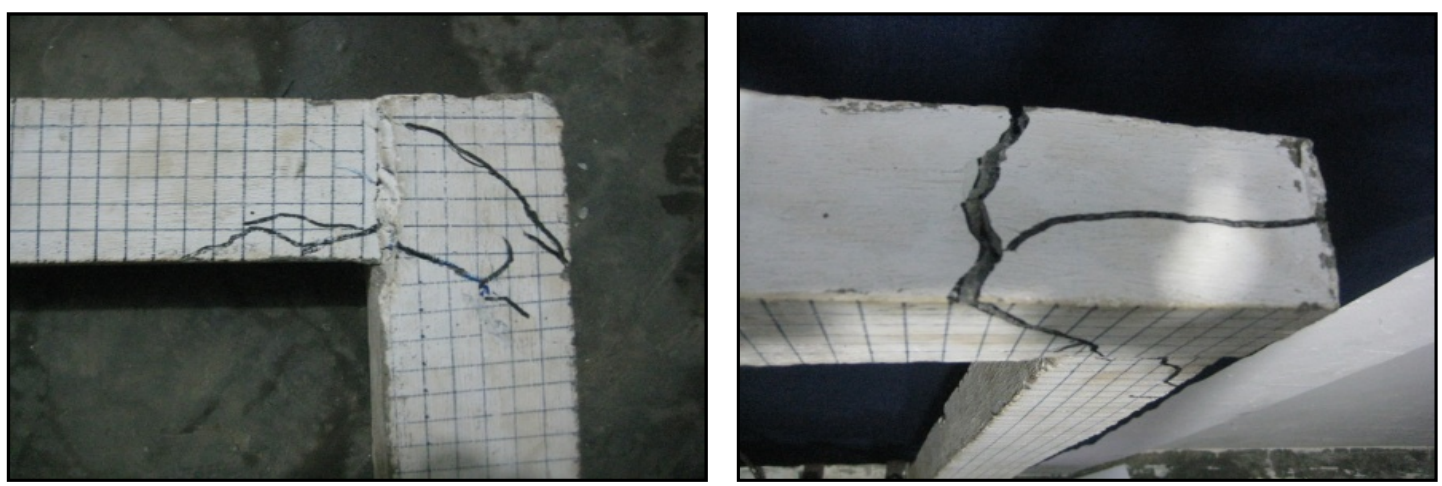

Gambar 9. Pola Retak pada Sisi Kanan Portal Kolom Kuat - Balok Lemah

\subsection{Balok Kolom Sama Kuat}

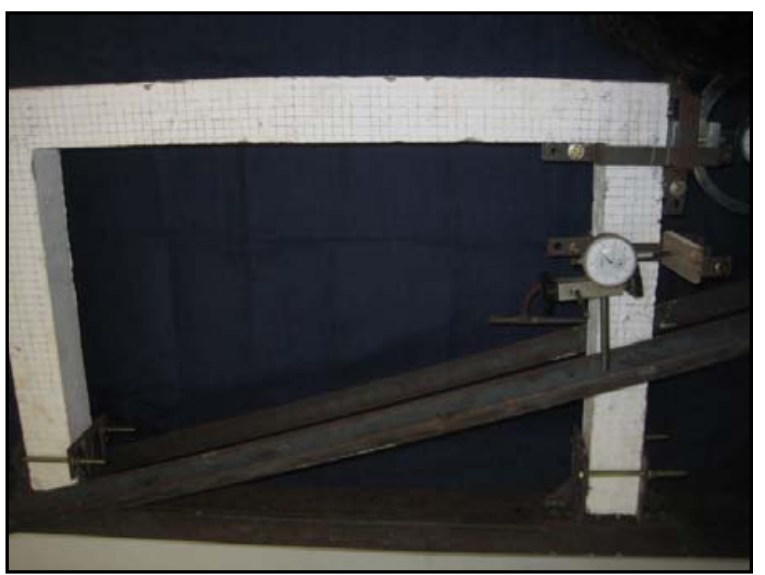

Gambar 10. Gambar 4.4 Portal Balok Kolom Sama Kuat

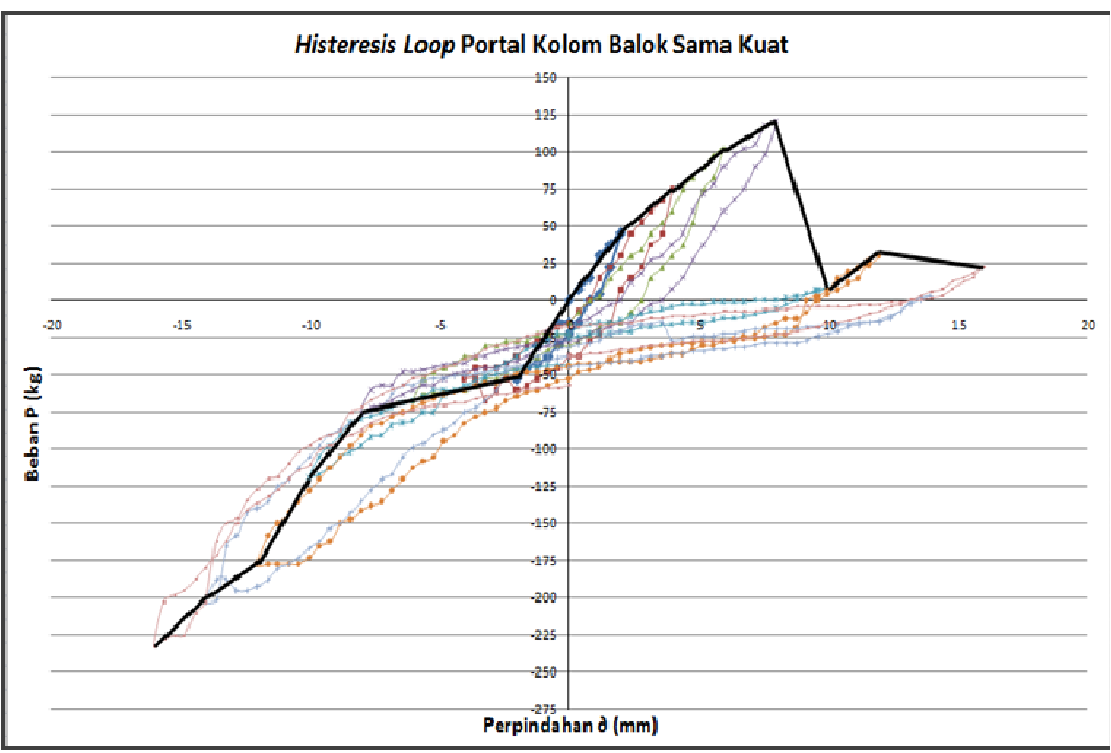

Gambar 11. Kurva Histeresis Kolom- Balok Sama Kuat 


\subsubsection{Kondisi Tekan}

1. Retak Pertama

Pada benda uji portal tipe 2, retak pertama berada pada sendi plastis yaitu pertemuan kolom dengan balok. Dari pengamatan pola retak yang terjadi pada benda uji, kolom yang pertama kali mengalami retak diikuti dengan retak pada balok. Retak pertama ditandai dengan tidak liniernya kurva beban dengan perpindahan akibat beban dorong tekan sebesar $45 \mathrm{~kg}$. Perpindahan yang terjadi pada retak pertama sebesar $2 \mathrm{~mm}$.

2. Kondisi Leleh

Pada saat leleh diikuti dengan retak-retak baru pada bagian sendi plastis lainnya, sedangkan tumpuan (dasar kolom) tidak mengalami keretakan. Beban tekan pada saat leleh adalah sebesar $102 \mathrm{~kg}$ dengan Perpindahan sebesar $6 \mathrm{~mm}$.

3. Kondisi Ultimit

Ini tejadi ketika portal memikul beban maksimum namun portal belum runtuh. Beban maksimum adalah sebesar $120 \mathrm{~kg}$ dengan perpindahan sebesar $12 \mathrm{~mm}$.

4. Keruntuhan portal

Ini tejadi ketika beban tidak lagi bertambah dan beton mulai hancur. Beban pada saat runtuh adalah sebesar $4,5 \mathrm{~kg}$ dengan perpindahan sebesar $10 \mathrm{~mm}$.

\subsubsection{Kondisi Tarik}

1. Retak Pertama

Pada benda uji portal tipe 2, retak pertama berada pada sendi plastis yaitu pertemuan kolom dengan balok. Dari pengamatan pola retak yang terjadi pada benda uji, kolom yang pertama kali mengalami retak diikuti dengan retak pada balok. Retak pertama ditandai dengan tidak liniernya kurva beban dengan perpindahan akibat beban dorong sebesar 52,5 kg. Perpindahan yang terjadi pada retak pertama sebesar $2 \mathrm{~mm}$.

2. Kondisi Leleh

Pada saat leleh diikuti dengan retak-retak baru pada bagian sendi plastis lainnya, sedangkan pada tumpuan kolom tidak mengalami keretakan. Beban tarik pada saat leleh adalah sebesar $75 \mathrm{~kg}$ dengan perpindahan sebesar $8 \mathrm{~mm}$.

3. Kondisi Ultimit

Ini tejadi ketika beban yang mampu dipikul oleh portal adalah beban maksimum namun portal belum runtuh. Beban maksimum portal adalah sebesar 232,5 kg dengan perpindahan sebesar $16 \mathrm{~mm}$.

\subsubsection{Pola Retak}
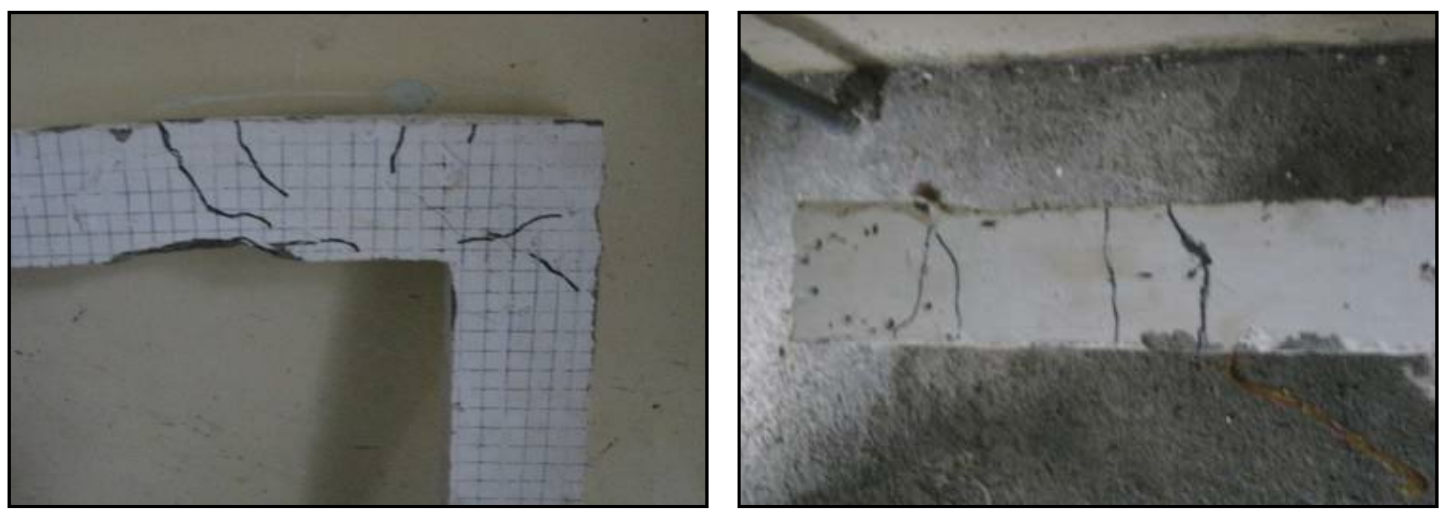

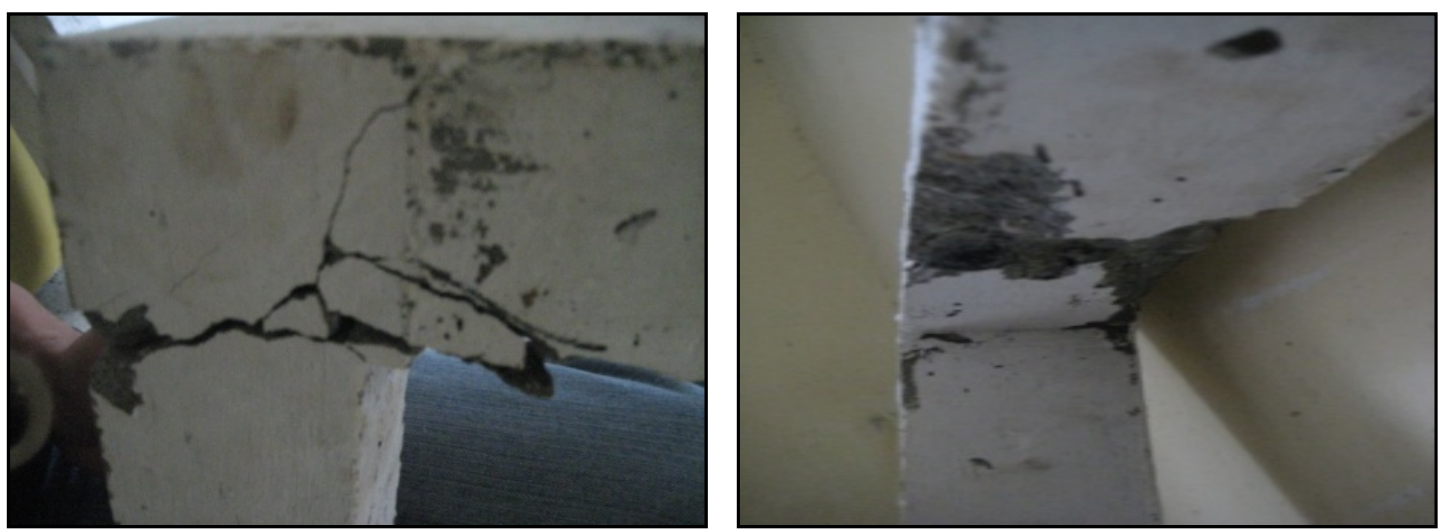

Gambar 12. Pola Retak pada Sisi Kiri Portal Kolom - Balok Sama Kuat
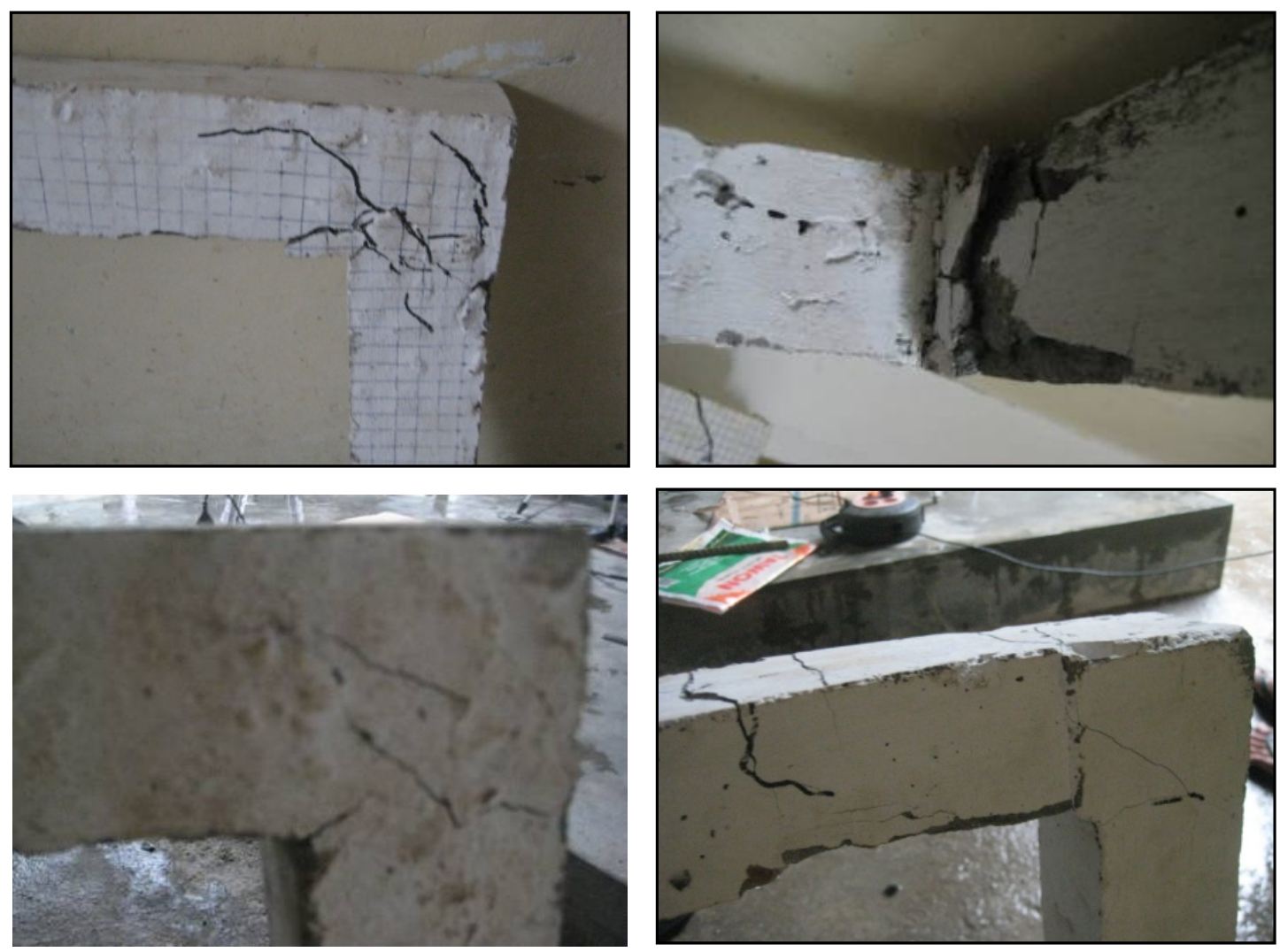

Gambar 13. Pola Retak pada Sisi Kanan Portal Kolom - Balok Sama Kuat

\subsection{Analisa Data}

\subsubsection{Beban - Perpindahan}

Portal kolom kuat - balok lemah mampu menerima beban maksimum sebesar $135 \mathrm{~kg}$ dan portal kolom - balok sama kuat mampu menerima beban maksimum sebesar $120 \mathrm{~kg}$. Ini menunjukkan seharusnya semakin besar dimensi balok maka semakin besar beban yang mampu diterima oleh portal. 
Hasil lengkap hubungan antara beban-perpindahan ditampilkan pada tabel di bawah ini :

Tabel 1. Nilai Beban Puncak dan Perpindahan pada Kondisi Tekan

\begin{tabular}{|c|c|c|c|}
\hline Benda Uji & Kondisi & Beban (kg) & Perpindahan (mm) \\
\hline \multirow{4}{*}{ Kolom Kuat - Balok Lemah } & Retak & 46,5 & 6 \\
\cline { 2 - 4 } & Leleh & 100,5 & 12 \\
\cline { 2 - 4 } & Ultimate & 135,0 & 18 \\
\cline { 2 - 4 } & Runtuh & 120,0 & 20 \\
\hline \multirow{3}{*}{ Kolom - Balok Sama Kuat } & Retak & 45,0 & 2 \\
\cline { 2 - 4 } & Leleh & 102,0 & 6 \\
\cline { 2 - 4 } & Ultimate & 120,0 & 12 \\
\cline { 2 - 4 } & Runtuh & 4,50 & 10 \\
\hline
\end{tabular}

Tabel 2. Nilai Beban Puncak dan Perpindahan pada Kondisi Tarik

\begin{tabular}{|c|c|c|c|}
\hline Benda Uji & Kondisi & Beban (kg) & Perpindahan (mm) \\
\hline \multirow{4}{*}{ Kolom Kuat - Balok Lemah } & Retak & 4,5 & 2 \\
\cline { 2 - 4 } & Leleh & 60 & 9,6 \\
\cline { 2 - 4 } & Ultimate & 147 & 18 \\
\cline { 2 - 4 } & Runtuh & 102 & 16 \\
\hline \multirow{3}{*}{ Kolom - Balok Sama Kuat } & Retak & 52,5 & 2 \\
\cline { 2 - 4 } & Leleh & 75 & 8 \\
\cline { 2 - 4 } & Ultimate & 232,5 & 16 \\
\hline
\end{tabular}

Tabel 3. Selisih Perpindahan antara Kondisi Tekan dengan Kondisi Tarik

\begin{tabular}{|l|c|c|c|c|}
\hline \multirow{2}{*}{ Benda Uji } & \multirow{2}{*}{ Kondisi } & \multicolumn{3}{|c|}{ Perpindahan (mm) } \\
\cline { 2 - 5 } & & Tekan & Tarik & Selisih \\
\hline \multirow{4}{*}{ Kolom Kuat Balok Lemah } & Retak & 6 & 2 & 4,0 \\
\cline { 2 - 5 } & Leleh & 12 & 9,6 & 2,4 \\
\cline { 2 - 5 } & Ultimate & 18 & 18 & 0,0 \\
\cline { 2 - 5 } & Runtuh & 20 & 16 & 4, \\
\hline \multirow{3}{*}{ Balok Kolom Sama Kuat } & Retak & 2 & 2 & 0,0 \\
\cline { 2 - 5 } & Leleh & 6 & 8 & $-2,0$ \\
\cline { 2 - 5 } & Ultimate & 12 & 16 & $-4,0$ \\
\cline { 2 - 5 } & Runtuh & 10 & - & 10,0 \\
\hline
\end{tabular}

\subsubsection{Pola Retak}

Pola retak yang terjadi pada masing-masing portal umumnya terjadi pada daerah sendi plastis, yaitu pertemuan antara kolom dengan balok. Arah retak yang terjadi umumnya sejajar dengan arah memanjang balok. 


\section{KESIMPULAN}

\subsection{Kesimpulan}

Berdasarkan pembahasan dan tujuan terhadap penelitian yang telah dilakukan, dapat ditarik beberapa kesimpulan antara lain sebagai berikut:

1. Semakin besar dimensi balok maka semakin besar beban maksimum yang mampu diterima oleh portal. Pada portal balok kuat kolom lemah, dimana beban maksimum yang diterima lebih kecil dari portal kolom kuat balok lemah.

2. Retak pada umumnya terjadi pada daerah sendi plastis, yaitu pertemuan antara kolom dengan balok. Karena retak yang terjadi hanya pada sendi plastis, maka portal kolom kuat - balok lemah dan portal kolom - balok sama kuat, sangat cocok

3. Keruntuhan portal pertama sekali terjadi pada balok yang kemudian diikut dengan keruntuhan kolom.

4. Sistem portal kolom kuat - balok lemah dan portal kolom - balok sama kuat sangat cocok digunakan pada struktur bangunan yang terletak di wiayah rawan gempa.

\section{DAFTAR PUSTAKA}

Departemen Pekerjaan Umum, (2002), Tata Cara Penghitungan Struktur Beton Untuk Bangunan Gedung SNI 03-2847-2002, Yayasan LPMB,Bandung.

Departemen Pekerjaan Umum, (2003), Tata Cara Perencanaan Ketahanan Gempa Untuk Bangunan Gedung, SNI 03-1726-2003, Badan Standardisasi Nasional.

Park \& Paulay, (1975), Reinforced Concrete Structure, John Wiley \& Son Inc, Canada 
Kajian Eksperimental Pola Retak pada Portal Beton Bertulang Akibat Beban Quasi Cyclic

\section{6 | J URNAL REKAYASA SIPIL}

